\title{
The Construction of Marginality of Border Areas: A Case Study of Natuna Island in Indonesia
}

\author{
Marsetio $^{1}$, Irwan Abdullah ${ }^{2}$, Rudiyanto ${ }^{3}$, Zaenuddin Hudi Prasojo ${ }^{4}$, Ririt Yuniar ${ }^{5}$, \\ and Rajab Ritonga ${ }^{6}$ \\ ${ }^{1}$ Indonesia Defense University, Bogor, West Java, Indonesia \\ ${ }^{2}$ Universitas Gadjah Mada, Yogyakarta, Indonesia \\ ${ }^{3}$ Biro Klasifikasi Indonesia, Tanjung Priok, Jakarta, Indonesia \\ ${ }^{4}$ Pontianak State Institute of Islamic Studies, West Kalimantan, Indonesia \\ ${ }^{5}$ Universitas Pancasila, Jakarta, Indonesia \\ ${ }^{6}$ Universitas Prof Dr Moestopo (Beragama), Jakarta, Indonesia \\ *Corresponding author: rajab.ritonga@dsn.moestopo.ac.id
}

\begin{abstract}
This paper presents the construction of marginality of border areas of Natuna Island in Indonesia. Firstly we present the state views and makes construction of marginality toward Natuna Island as a border region. Secondly, we present kinds of political and social-cultural practices are done in the process of marginalization of Natuna border region. Finally, we present the response of people in Natuna to the marginality construction by the state. We conclude that there are three aspects relating to the construction of the border community, especially the marginalization of Natuna by the central government, namely: politics, socio-economics and culture.
\end{abstract}

Keywords: Construction; Border Marginality; Natuna; Indonesia

\section{Introduction}

The geographical position of Indonesia which located between the continents of Asia and Australia and between the Indian and Pacific Oceans is an important fact which leads to many strategic issues. Indonesia's sea directly connects with many countries such as Malaysia, Singapore, Philippines, Vietnam, and also connects to South China Sea on the north part. In the south part, it borders with Australia, the Indian Ocean and with Papua New Guinea, East Timor and the Pacific Ocean in the east. Indonesia has also land borders with three countries including on the island of Borneo with Malaysia, on the island of Papua with Papua New Guinea and on the island of Timor with Timor Leste. Indonesia with approximately 17,499 islands, such as Sekatong and Ambalat islands, scattered bordering with neighboring countries have increased the complexity of the border issue both on the question of foreign and domestic concern [1]. The position of Indonesia archipelago is unique, formed by the confluence of three giant plates of the earth including the Pacific Plate, Eurasian Plate and the Indian Ocean-Australian Plate. Therefore, it is not surprising that Indonesia is rich with various natural phenomena (earth phenomena). The most prominent natural phenomenon is an area of Sunda land which has a shallow sea on the west, the areas with deep-sea trenches in the middle i.e. Banda Sea and the Exposure to Sahul by a shallow sea on the east end. From Sabang to Merauke archipelago lies in the path of the magnetic and seismic lines and lines of negative gravity anomaly in the world's longest. On the basis of such a unique geographical position, lay a vast sea of the archipelago with a strong connection and a variation of the types of sea depth including shallow and deep sea that gives the beauty and diversity of marine life.

Received (March 15, 2017), Review Result (June 19, 2017), Accepted (August 19, 2017) 
This illustration shows the potential of the economy in the form of a potential mining, fisheries, ecosystem protection and maritime services in Indonesia. The geopolitical position of Indonesia, which borders with 10 neighboring countries, confirms the existence of external factors as a trigger for a variety of issues that have broad implications. These issues include the determination and the agreement of border areas, the claim over the islands, marine resources, security breach, border crossing committed by people from the neighboring countries and the issue of the existence of a border. The empowerment of marine border areas in particular has an important meaning to the sovereignty and integrity of the Republic of Indonesia. The geopolitical and geostrategic of Indonesia is a key to international maritime transportations and communications such as the Sea Lanes of Communication (SLOC) and the Sea Lanes of Transportation (SLOT) with is a dynamic aspect that needs to be continuously managed based on the development of a political constellation. From the domestic perspective, some important issues that need more care such as the issues of nationalism within people living on border areas, improving the quality of human resources, infrastructure improvements and quality life improvements become the focus of long and tiring debates. In fact, the existence of the border remains a burden in those debates due to the vulnerable position of Indonesia border areas in various dimensions. Level of overseas migration in the border areas is very high and even shocking with the fact that more people of border area residents working abroad, mainly to some neighboring countries. The loyalty of the people living in border areas of the county has always been an important question that requires substantial responses.

Attention and commitment of the government strongly support the existence of the border areas with multidimensional issues. One thing that must be recognized is that the position of border areas and outer islands is geographically a distant form the center of government. In fact their position is very strategic because they are located on the front lines directly adjacent to the territory of another country. The issues of border regions are basically derived from the position of areas that are geographically distant from the central government. This position tends to lead the people of these areas to have less access to various facilities, although they are fully aware that their position is very strategic, which is in the front line and immediately adjacent to the territory of another country. Border areas as a buffer area (safety belt) are expected to prevent infiltration of outside influences in various aspects of life [2]. In the context of an islanded nation, unity and border insecurity, especially with regards to the outer island, needs a special attention due to their strategic position. The issues of insecurity could be seen, among others, in the unsuccessfulness of a number of sea border issues with some neighboring counties and the increasing of human smuggling activities using the order regions as a mean of transit to go to another country. The central government could give some attentions to people of border areas and outer island in many ways including community development, security areas and capacity building of human resources. Indonesia's border regions are thought to have high potential and strategic values in supporting national development program [3]. This strategic position of border area is a solid foundation to make the border region as a center of development discourse and practices.

Geographical position and strategic location of border area is not followed by the development policies of the central government concerning the existence of the border region. Otherwise, the regions get a variety of marginalization including politics, economies and culture. The notion of the border issue as a marginal area could be seen at the less touching policies; the polices do not touch the improvement of life quality of the people of border areas and the infrastructure is also very poor. Most of border areas have tremendous potentials but less attention and not well and seriously managed. Border area is categorized as disadvantaged areas with very limited basic infrastructure and does not receive sufficient and comparable attention to utilize the potentials and strategic position [4]. Moreover, the development program of border areas that has been done tends to 
employ the security approach which is not in the favor of the grass-root people of the border areas.

In Natuna, as one of the border areas, some important border issues occur in response to the current condition. They include a little attention by the national development program, geographic issues, debates of border line, poor management of natural resources, weak management of protected areas across the country, lack of legal support for development actors in the border regions, unclear legal status of borders, lack of linkages between natural resource managers with socio-economic population, security and political aspects that can interfere the relations with neighboring countries, community marginalization and the inability of people in the border areas in accessing high technology. In addition, investments in border areas are still very limited. There is a notion that border areas have not been thought to bring significant economic benefits. The aim of the development program by the central government, in fact, is said to improve the dignity, prestige, quality and welfare of all people of the country [5]. Yet, it has not happened in border areas such as Natuna Border area, weak in quality of human being, the source of conflict, a threat to the homeland, and narrow nationalism [6]. In other words, the borders tend to be associated with area with problems.

The social construction of the border area shows a contradiction. On the one hand, the border has been seen as a suburb with all limitations and portrayed as the source of the problems with people of doubtful loyalty. Such discourse has been built by the state for the sake of upholding the sovereignty and integrity of the Republic of Indonesia. The state demands its people to be good citizens and loyal, as a classical approach to the hegemonic relations established in the country and its people [7]. People living in the border areas are considered vulnerable to escape to become a neighboring country citizen.

On the other hand, the border area is considered and rates as the vanguard of Indonesia. Border area is a crucial stronghold, dealing directly with neighboring country territories. Later on it becomes a central position, since it determines the diplomacy between the two countries, Indonesia and neighboring countries, which are determined by the existence of a border region. However, the discourse seems to develop in a negative notion because in practice border area is considered as an object and the people living there are left behind in many aspects including in the consultation of border issues. It is important to consider and discuss how the border areas and the people of border areas experience the direct consequences of the marginalization process that has been at stake. The demand for equity of citizenship is an obvious action and attitude by people of border areas like Natuna by complaining their existence as the periphery to be considered as an important gateway to a country that deserves to be treated better in the development program. They also reject the marginalization in many terms including economics, social, cultural, educations, class, power and even social networking information. The attention and public participation in urban areas that have been the priority in development program could be a bad precedent of the existence of border areas or outer islands that have been marginalized for a quite long. If such policy continues to be implemented, it will lead to negative impacts on sustainable development of the country in general [8]. Moreover, the threat of disintegration will emerge in the border area and outer islands due to the lack of emergence of disengagement (ignorance) of society, in the absence of attention of the central government [9]. Nevertheless, this situation needs a thorough action to deconstruct a new discourse of border areas. The area should not be marginalized in many aspects including the use of terminology (language), social and development. The development program undertaken by the New Order government, implementing a centralized system, leads to the marginalization of periphery areas. Centralized political system implemented effectively by the New Order era encourages the absorbance of various potential by central government resulting in the weak position of the periphery areas. Slowly but surely, the centralized system of government continues to do the exploitation of natural resources from the countryside. The border and remote regions experience 
impoverishment. This process of cultural and social marginalization also leads to marginalization.

The construction of marginalization by the government, in turn, is unconsciously reproduced by the citizens or people in border areas. Through the development program in the New Order era, which is continued in the era of reformation, the government continues to run a program called development program for disadvantaged areas. Furthermore, the government has established the Ministry of Rural Development to take care of the disadvantaged and marginalized areas. Initially the program aims to encourage the suburbs to be more actively involved in the development process, but it strengthens marginality, especially in border areas and outer island such as Natuna Island. Based on the description given above, the questions discussed in this work are given as follow:

a. How the state views and makes construction of marginality toward Natuna Island as a border region?

b. What kinds of political and social-cultural practices are done in the process of marginalization of Natuna border region?

c. How is the response of people in Natuna to the marginality construction by the state?

The rest of this paper is given as follow: Section 2 presents some explanations, definitions and typologies of border region in order to give understanding about border issues in Indonesia, especially in Natuna District. Section 3 presents results and following by discussion. Section 4 concludes this work.

\section{Definition and Typology of Border Region}

The boundary of a state is known at that same time with the birth of the state concept. The in modern definition has been known since the $18^{\text {th }}$ century in Europe. The state boundary is the geographic space which, since in the beginning, constitutes of the region of scrambling power among the bordering states, mainly coming from disputed areas as a result of geographical expansion efforts by the bordering countries. As a part of the history and the state existence, the story of border region may not be separated from the history of a country. In this case, it is interesting to see and discuss the history of the birth of the nation-state concept as the modern state form which continues to develop in line with the issue of ethnic nationalism and national identity. Smith [10] explained that national identity as a collective cultural phenomenon contains some basic elements such as language uniqueness, sentiments and symbolism tightening the relationship of the community member living in a certain territory.

In early of its birth, nation-state, according to Smith, is identical with "ethnic state". In the beginning, the territorial boundary of a national-state is the reflection of a geographic border of a certain ethnic group. The following development of the nation-state practices show that the same dream, which could be a cross-ethnic dream, dominantly appears to be the basic of the existence of a nation-state. The border of state, in that context, shows a certain complexity indicating that a state border does not only break up an area of different ethnicity but also of similar ethnicity due to a certain experience of different nation histories by the people from same ethnic group.

A border region between the bordering countries plays a strategic potential for the development of international commerce activities that give benefits to the counties. This region also is a big potential to become the center of development of territories, especially in the case of industry development, commerce and tourism. This will give opportunities to the increase of the production activities which could give some multiplier effects [11].

Looking back at the definition, the general definition of the border region is a demarcated line between two sovereign states. In the beginning, the state's border is formed with the birth of the state. Previously, the people living in a certain region would not feel the difference of becoming a citizen of a country. They are, in the same cases, 
even from a same ethnic group. With the birth and the existence of the state, they are separated and they should have a different citizenship due to the demand of the state.

Tirtosudarmo quoting Ricklesf [6] mentions that the borders so-called Negara Kesatuan Republik Indonesia (NKRI) are related to the history of the power of Dutch colonial army. Martinez as quoted by Tirtosudarmo [6] categorizes border type into four. Frist is alienated borderland; a border region in which there is no activity of border crossing as a consequence of war, conflict, domination of a nationalism, ideological hatred, religious hostility, cultural differences and ethnic competition. Second is coexistent borderland; a border region where cross border conflict can be taken care and control although there still some small issues occur related to the matter of the border strategic resources. Third is interdependent borderland; a border region where both sides are symbolically connected by a more stable international relation. The border or citizens in the both side of the border region, and in both countries, get involved in some economic activities that give advantages each other and approximately at the parallel level, for example, one of the side has production facility whereas the other one has cheap labor. Fourth is integrated borderland; a border region where people in the region apply an integrated economic system. Nationalism of the people in the both states is less strong than their feeling of alliance.

A typology of border region represents a series of development model. According to Ratti $[12,13]$, the development of border region is a process of action beginning from the notion that the border region as a frontier area is a barrier, becoming a filter, then moving to be a contact zone. For example, in the case of Hongkong-Shenzhen, economic relation runs in a close and symbiotic way. Some institutional sketches appear by consultation. Company relations mostly are formed in a joint venture model. The planning of infrastructure network sometimes contradicts but move toward the consultative planning. Migration is tightly controlled and the difference of labor's salary is big enough [14,15].

The development of border region aims at gathering and grouping the existing characteristic at the border region and identifying the key barriers and the needed policies demanding for bigger attention if the development plan to be continued with ore advanced program at the next stage. This development approach includes three models. First is a planning by making priority of building infrastructure (infrastructure led) as the investment before the economic activity start. Second is planning by making a priority for the private sector investment (investment led). And third is a planning by making the programs and policies (policy led) as the priority aiming at facilitation the development of the border region. There are significant differences in this category showing the existing dominant characteristic. Therefore, this approach works at three kinds of border regions [16], namely the region of border, cross border, and trans-border.

There are some arguments of fiving limitation of the three regions. Why border? It is because the border region constitutes of zones where two or more cultures, societies, nations, tribes or modes of the certain production interact. Another problem is that, why trans-border? This is because there is a notion held by the central government that border area is a zone vulnerable from influences of foreign propagandas and provocations which could become serious threats.

\section{Results and Discussion}

\section{A. State Marginalization to Natuna}

The marginalization of Natuna is also a part of the marginalization of the maritime sector as an implication of the bias concept of agricultural development in Indonesia. As a consequence, Indonesia as a maritime country does not apply its development program on the basis of maritime concept of development. Furthermore, the maritime sector in the country (maritime country) is also marginalized, together with the people of maritime border. Therefore, it can be understood that people of the border regions are synonymous 
with poverty. In fact this is so. It is an irony of Indonesia, a country with claim of a maritime country and the history of maritime glory but neglecting maritime sectors and people. Jalesveva Jayamahe motto (it was in the sea we got victory) seems to have become a kind of myth.

It is widely known and already becomes a classic story that in today's era of modern technology, the Indonesia marine water which is very rich in food sources has been explored more by foreigner, foreign fishermen. Most of Indonesian fishermen are, in fact, still struggling on the lack of technology and still use traditional and cultural equipment in exploring the Indonesian maritime water. As a result they are very poor and only able to fishing to the sea with traditional equipment. While foreign ship with modern fishing and fish processing technology have better access an even "free" to take tons of fish in water of the Indonesia archipelago.

Fishing boats from Thailand, Malaysia, and Vietnam that ship with a capacity of 60 to 100 GT continue to catch tons of fish freely in the Indonesian sea, in Natuna sea border. Natuna fishermen have only been able to go fishing in the beach area, while some miles away from them in the Indonesia sea in Natuna islands many foreign fishermen freely to fishing and take tons of fish from the sea. The Natuna fishermen in the border area could just watch them catching fish since they could do nothing and powerless. This happens almost every day and lead to influence the psychological condition of the Natuna fishermen which in turn makes them sad and but helpless. They said that they would choose not to get ship from the central government if the ships would not be able to help them catch fish in the sea and compete with those foreign fishermen. As a matter of fact, every time they complain to the government, they get some small capacity vessel which could not support them to go fishing to the sea. They cannot use the ships go to the sea because the ships are not strong enough for large waves. In addition, the political condition and environment after independence of Indonesia, especially by the coming of the Army into a political force, further confirms the position of Indonesia development orientation, which is land or agriculture oriented rather than sea or maritime oriented. In New Era, the centralized political and economic system puts Java completely as the center of Indonesian development program. On the basis of that historical development concept, Indonesia as an archipelagic state or country or maritime-based country had been deconstructed to besome "land" or agricultural based country based in Java. The construction of the "land" country which glorifies the political and economic centralism has huge implications for the border regions and outer islands, and thus they had been marginalized, excluded and neglected [6].

The pattern of management of natural resources tends to use an agricultural country perspective rather than a maritime nation perspective. This is an ironic of considering that three quarters of the area of Indonesia is marine water and the fisheries potential is enormous. Therefore, if we want a true people's welfare, it is time for us to shift our development policy direction to get more attention to the management of natural resources in the maritime sector. Along with that, it means also that in an effort to improve food security, the government also should change this paradigm since the shift from central attention to the border area or periphery focus need long process. There should be a paradigm change from an agricultural country to a maritime nation. Some various issues concerning to maritime borers with regard to disputes with neighboring countries still remain unsolved. Those unsolved problems could potentially lead to conflict and insecurity of the country's sovereignty and security conditions in the border areas. It is not just about the unclear boundary area of Indonesia with neighboring countries, but also about the condition of the people residing in border areas. Over the past 50 years, the maritime sector had been marginalized along with the bolder population, This fact suggests that the socio-economic conditions and development in border area is very far behind. The minimum of health facilities, education, transportation and communication, the absence of an integrated policy for development of economy centers on the border led to numerous acts of infringement. 
Government policies relating to border management have been unable to increase the improvement of infrastructure and welfare of the citizens of border areas. This shows that those policies are mainly centralized, top-down and less open participation of citizens in the border so that they have not been able to better respond to the problems and real border issues. The problems that arise relate to border dimensions range from the technical aspects of the determination of the border to the legitimacy problems that occur in the border region and include all aspects of national life including ideological, political, economic, social, cultural and even security and defense. The border regions have a very important and strategic role since they are not only the border of a country but also areas that reflect the front page of a state. Various problems arising related to border issues will have implications to national defense and security issues. These issues must be resolved so that later on they will not be detrimental do national interests of Indonesia. Therefore, of central government, local governments and all components of the Indonesia people in the settlement should give more the attention to these marginalized border areas and outer islands.

The government development policies for the border area have been mostly oriented to handle the issues of illegal activities such as the smuggling of people and goods and other matters relating to relations with neighboring countries. It should be recognized that so far the attention has been given to territorial defense aspect, while the defense functional forms such as economic empowerment and socio-cultural approach have been at concept level and not yet implemented or even neglected. Some development programs having been implemented such as the construction of roads, economic centers, educational facilities, health centers and other social facilities are seen less well planned do that the results are not optimal and proved to be unsustainable. In addition, the programs implemented by the central government are not in line with local needs. Border regions have not been put as a priority in development programs of border areas even still considered as the "back" not the "front" line of the country.

In the management of border areas, the government pays little attention to economic aspects and social and cultural borders. If we really want to make the border region as the nation's front page, then the infrastructure should be improved to support all aspects related to the economic characteristics of the territory without neglecting environmental aspects. Lack of attention in the management of the border region also leads to the neglecting of the maritime sector. Yet, the fact shows that scientifically the wealth of the Indonesian oceans contain abundant natural resources. The potentials of marine resources owned by Indonesian in the border regions that have not been explored are unbearable to the stealing of natural resource by neighboring countries. In addition, the people of the border areas have not been able to explore the potentials due to the lack of facilities and infrastructure to support economic activities base maritime sector in the border regions. The development programs for the border area have not employed the participatory approach. The construction of the border areas is still determined mostly by the central government. Local people of the border areas have not been actively involved in developing their land so that the needs in the areas have not been well identified as every region has different characteristics. The central government runs the development policies and programs in a general assumption to all regions and does not pay attention to local aspirations and the uniqueness of each border region.

\section{B. Marginalization of Natuna Border Region}

There has been a notion that the officials from the central government (Jakarta) normally consider the border areas as a place to visit. Several ministries have made some visits with and designed some supporting programs then left them without evaluation and further actions. There is an impression that the spirit of such programs is only for the absorption of the budget planning; they are not seriously intended to be of helps for the people of border areas and outer islands as an effort to improve the quality of life. This 
phenomenon is often called as the phenomenon of "state visit". That is to confirm that, so far, the border areas are often considered as targeted places for visits by officials from Jakarta. Some officials go and visit Natuna, for example, with some aid promises, but they do not go their promises. Development programs have not been seriously designed for the marginalized border areas like Natuna.

There are some issues of incompatible aid with regards to Natuna case including in the context of the need of fishermen conducted by the Ministry of Communications and Information Technology. For example, the telecommunication equipment assistance program for the "Information Village" program. The program goal is to help people in the border areas connect with outside world and become informers for the country and other people by using border telecommunications facilities such as telephone, television, a set of community radio, and a set of internet network. The programs of "Information Village" is actually with a good purposes including improving the feeling of nationalism and the welfare of border communities though access to media information. However, the program does not work well as expected because of the implementation of the top-down approach and the ignorance of the local existing social institutions involve in the program.

The incompatibility of assistance or aid program form the central government suggests that the government still applies the top-down and dropping approach for aids and assistance programs although they are in the era of democratization, the top down approach could be traced back to the history of New Order with strong centralize power by Jakarta. At that time the concept was launched in response to the increasing trend of a more centralized development pattern to use the top-down approach. Various development programs at time were coming from government initiative, while the initiatives form people were less accommodated within the development planning process. Participation was the understood by a single interpretation of the government, which is meant the extent to implement the community development program that is designed from the top, from which have been set by the government. There is an impression that the government's attention to the border regions is only though a political attention. The central government is concerned with the political objectives including avoiding border rebellions; it is not based on a commitment to strengthen the nation with a concept of border development program. In other words, the periphery areas are put as less important and even unimportant than other parts of the Indonesian territory especially Java. The central concern is manly in Java as the font land. The central government is afraid of losing popularity on the eyes of border residents but does less to help them compare to what is done by the governments of neighboring countries with regards to border residents.

That political practice by the central government indicates that the government has not yet positioned the border region as the starting point of nation building. It may be because of the implication of the centralize development system heavily influenced by Javanese culture, as effectively applied during the New Order era. It has long been the choice of the development paradigm in Indonesia to use centralized approach that greatly influenced by the Javanese concept of power. This model is applied effectively in the era of new Order with Jakarta as the center point and at the same concentration of power. Centralized development under New Order Era leadership was greatly influenced by the power model of Java with the king and the palace as the center. Anderson $[17,18]$ describes a model of centralized power of Java by using the metaphor of a shining lamp, in which the farther away an object is located from the light source the less it will receive the light. It is clear that in the New Order era border regions received only a dim of light bulb which is sometime increasingly disappearing. It is also true that the attention of national government in the border areas geographically located on the periphery is not as strong as much attention to the area close to the center. The practice of this marginalization by the central government still continues until the current Reformation era. Natuna fishermen narrative about aid equipment from the central government that does not comply with 
community needs to the evidence of the continued practice of marginalization on the border areas.

\section{Central's Construction And Citizen's Resistance}

Natuna has similar position with some other peripheral regions in Indonesia with regards to politics, social, economic and cultural affair with the central government. Since in the beginning, Natuna has been perceived as an important border area but in the point of view of exploitation by the central government. There is no chance for the border region like Natuna to construct its own position, either in the politic, economy or socialculture. The state as the main actor has played as the one constructing the existence of Natuna as a peripheral district. In the terminology of cultural studies, the central government takes a role as the dominant narration having full power to construct the identity of Natuna's marginality. The state (read: centre), since New Era administration has seen Natuna as a "special viewed" political and cultural entity. That giving position leads to the issue of the forming process of Natuna's identity as the peripheral district. For the central government, Natuna is assumed as the political region while, at once, as the cultural region which has to be controlled. The state's instruments such as military base camps and political institutions operating in Natuna have to be designed from the center. The people of Natuna have not been assumed as considered as an entity which can do anything suiting their wills and aspirations. It is not surprising if Natuna people are not allowed to manage their district before the establishment of the Natuna District.

The central government tendency to put Natuna as the object can be seen from many program of national development in with people of Natuna must follow the order of the central government in developing the region. The way of the state running the development programs of this region is not with the participation and the aspiration of Natuna citizens but all are decided from the center (Jakarta). As a consequence, this region is considered as a marginalized. In addition, Natuna is also put in a group of regions receiving the transmigration program. Through the transmigration program, Natuna people are "forced" to learn doing agricultural activities and the have to learn from the Javanese who participated the transmigration program. Besides that, the marginalization of Natuna by the central government is also done through the development model using top-down approach. The chosen applied model does not accommodate the aspiration of Natuna citizens. Therefore, when the central government does the modernization, Natuna must follow the program. When the central government applies the development approach with economic development orientation, Natuna is also designed to support the economic development by exploiting the natural resources, mainly mineral, oil and gas sectors.

There are two implications resulting from the use of development approach with economic development oriented in Natuna. Fisrt, this region become one of the exploited region, especially ol and gas sectors including liquid natural gas (LNG) in Anambas. This exploitation process of natural resources is followed by money taking by the central government, especially in New Order era. This condition provokes the decreasing of economic and social phenomenon which takes forms including poverty in the area of the sources of natural resources. The citizen of Natuna at the times was like "a died-chicken at rice barn". The exploitation of the natural resources gives bad psychology atmosphere of Natuna citizens. They, every day, see how the workers of the gas mine, most of them are local migrants from Java and Sumatra, live prosperously with the luxurious life style, whereas they could only watch. There was no protest appearing at the time because the political system was very authoritative and the citizens were not brave enough to express their aspiration for justice. At this point the citizens of Natuna experience the marginalization of social-economical as the consequence of the central government construction toward Natuna, which indeed, since the beginning was considered and positioned as the peripheral citizens that did not have to be given attention. The politic of 
marginalization remain there systematically through the bureaucracy by some regulation that must have been brought form Jakarta.

As the response of the marginalization construction by the center, by using the momentum of the political system change from the authoritarian to the democratic one in 1999, the citizens of Natuna did resistance toward the central government by demanding Natuna to have its own government with a regency status. It should be noted that at the time the government was not very dominant like in New Order era. Yet, it does not mean that the success of the process of the making of the Natuna district is without the citizen's struggle. The change status of Natuna to be a regency is a political struggle of the society and even is the struggle of people to fight against the central government as the consequence of the central government policies that marginalized Natuna for a long time. After the change of the political system by the end the New Order era, the people of Natuna begin to be brave enough to express their political will by using the democratic momentum running in Natuna. Some figure or local elite of Natuna such as cultural leaders, religious leaders, Non-Government Organization activists and the political figures do consolidation to fight against the central government in order to establish Natuna as a district. The awareness of Natuna citizens had grown since long time that one of the main factors of the Natuna's poor condition in the development sector is because of its status was just sub-district that did not have big financial budget for the development in the region.

The delegation consisting of some society figures of Natuna in 1999 went to road for a demonstration at the State Department and Financial Department, with a demand of the independent district status of Natuna and the profit sharing of oil and gas. According to Hamidi, an informan, before the Natuna district status was approved, the region did not get the profit sharing of the oil and gas due to the sub-district status. After the district status approved, this region gets a quota of profit sharing from oil and gas as much as 10 percent from the result of the total production. In Hamidi's view, in the past Natuna did not obtain profit sharing of oil and gas because the province controlled it and then gave it to Regency of Riau Archipelago. In the past, Natuna even got a small profit sharing of oil and gas through Riau Province with the quota of profit sharing from the central government. This psychological condition had also prompted the people of Natuna to demand the central government for more attentions and concerns. After passing the process of negotiation, competing argument and opinion with some related senior official in Jakarta, finally Natuna was approved as an independent district region by the Law Number 53 in 1999.

For the first time Natuna as Regency conducted a local election for a regent through voting at the local House of Representative of Natuna in 1999. The new era of the political government has significant effects on the development dynamic in some sectors. With regard to Natuna relation to the central government, as the autonomous region Natuna has the right to be involved and even take the lead in the management of the natural resources and the other natural resources of Natuna. The government has made some law regulations giving some district or regency regions authority with the Law Number 32 in 2004 about local government and the law of financial balancing. As the implication from the prevailing law, Natuna has got authority to take some profit sharing of the oil and gas production. However, after Natuna becoming independent regency, it does not mean that the process of marginalization had ended. It is true that in the management of the natural resources, Natunas's position remains to be assumed as the peripheral region. In this case, the state, indeed, has made some regulations that give a little profit to the region. In that case of managing and power sharing of the natural resources, the local government remains getting less advantage. As the illustration, for example, although in the political structure there is a law that gives an autonomous region and the financial management, Natuna's position as the peripheral region remains at the weak side of the bargaining. 
There appears a kind of form of resistance toward the state by using political language. With regards to its relation with the neighboring state of Malaysia, the citizens of Natuna do not put themselves at the space of the state boundary. For Natuna, what is understood by the state as the boundary, understood by them as their place where they can wake up early in the morning and manifest their existence every day. In this space, they create celebrate, identify and produce life reproduction, culture, and religion. Yet, Natuna's position is presented differently by using state ideology. Finally there arises the expression form some Natuna's citizens using threat language to associate with Malaysia. The expression is always stated when something happens making the Natuna's people disappointed. This phenomenon is like what France philosopher, Jacques Derrida, calls as "difference". It is a way to play the "language", a way to speak to fight against the dominant structures of the standard and organized language normally used to represent of a discourse, which is a discourse of marginalization of Natuna, in the context of Natuna. This can be understood as a form of separatism but as only a way of Natuna's people to negotiate with the state when the state officers are absent and just make ceremonial visiting to Natuna.

As the implementation of government policies to attempt to manage the border area, has established the National Agency for Border Management. The agency is a solution to the complexities and challenges faced. Body chaired by the Minister of Home Affair to take care of not only the boundary line, but also the region. The people of Natuna develop their identity from the past experience and present it with the language appearing and seen subversive containing resistance. Yet, they are actually trying to present themselves who are falling in the discourse of the modern state bringing their life too far to the peripheral area. Therefore, the struggle of Natuna's citizens in responding the dominant power of the state also becomes an issue of the national identity as an in-between-citizen who is marginalized by the dominant narration of the state.

\section{Conclusion}

Political dynamic in provincial and district levels cannot be separated from the political and economic dynamics happening at the national level. In the case of border issues, the changes and dynamics are reflected in the positioning and perception of the Jakarta as the center of the idea toward the border areas as parts of the periphery. In other words, changes in political science, economics, and culture occurring and happening in the border areas are related, and in some cases, determined by political and economic conditions in Jakarta and how people in Jakarta looking at border areas. There are three aspects relating to the construction of the border community, especially the marginalization of Natuna by the central government, namely: politics, socio-economics and culture.

\section{A. Politics Aspect}

The first aspect is politics in which the main issues of border area are related to the authority (power) space and range (distance). The construction of border areas by the central government is determined by how the central power (Jakarta) looking at the border from a certain distance, and then treating it as a space which is not only geographically, but also socially and politically. Hierarchical power relations, superior-inferior, the center-periphery as well as the inclusion-exclusion are a central issue related to the border issues. Consequently, some terminologies occur from Jakarta including the outer islands or the remote areas of Natuna, not Natuna as a leader of Natuna archipelago. The naming by the central government for Natuna border has clearly implied a marginalization. Therefore, it is not surprising that the central government treats the outer islands like Natuna as otherness (the others). Moreover, the positon of "the other" gets even stronger when the state implements a centralized political system where Natuna is in subordinate 
position by the central government. The state as the dominant position does a marginalization to the construction of the border regions including the Natuna District. Problems that arise in border areas, thus, have been closely linked to how the central government sees the border areas. This is a conventional point of view leading to position the people of border areas as static and homogeneous, isolated and alienated. That is why those in border areas far from the center, described as "tribes", and even, after the reforms, are still referred to as "remote indigenous communities".

The conventional and essentialist notion is ironically also embraced in academic circles led by Koentjaraningrat and the forwarded by Suparlan [19]. An example of Koentjaraningrat [20] view in this matter is reflected his book entitle "Masyarakat Terasing" (1993) and Suparlan writes a book called "Orang Sakai di Riau: Masyarakat Terasing dalam Masyarakat Indonesia" in 1995. Some implications of the rise of the discourse on "tribes" exhaled by the academic community include cultural assumptions about the growing inequality in the border communities, not as a matter of citizens presupposing the existence of cultural equality. The development of the viewpoint regarding the border resident with the bias of urban views is also a result of the construction of a nation state and narrow-minded nationalism which is essentialist. The point of view of nation-state and nation-centrist is later on imitated by local elites in Natuna. This is why in the context of border issues, the awareness of the "we" are still dominated by directors, officers, government officials that are officially on attributes such as state civil servants, policemen and local government officials. While many ordinary citizens still do not have the attitude to be parts of the "us" which already connotes as those who wear the formal attributes of statehood or a shirt "service".

\section{B. Socio-Economic Aspect}

The second aspect is socio-economic. Because Natuna has fairly rich natural resources, especially LNG, the control of the country is strong enough in this area. However, at the same time, Natuna is still seen as a poor and disadvantaged area with the aim that people in this region do not realize that Natuna area is rich. Therefore in Natuna, after the era of expansion with 1.2 trillion budgets, people who enjoy the fruits of development are some elite groups who collude with the central government, while ordinary citizens remain poor as it is before the division. The patterns of marginalization done by the central government in the era of expansion then are copied by local elites. Therefore, the process of development in Natuna is the also centralistic in the district capital, namely the City Ranai.

The Socio-economic marginalization is also seen in the fact that local conditions are still poor. Although the Natuna is an expansion area, local residents are still poor, and even the Chairman of the Community Periphery houses of Natuna (MPA) still lives in a sago palm house. In some fishing villages and rural areas, people are in poverty in the lowest level, as indicated in some conditions including far form decent home and the food availability at household are at minimal level. Every time a visitor from outside comes in, people would complain with the same message, which is about the attention of their fate from the central government.

\section{Cultural Aspect}

The third is cultural aspect. It is true that the presence of the central perspective also leads to a cultural marginalization. The presence of modernization brought by the development programs gives cultural implications of the marginalization of Natuna. All local value upholding honesty slowly begins to fade and marginalized. Therefore, the political elite as well as numerous government bureaucracies tend to ignore the local values. At first, a civil servant works with the newly accepted notion that corruption is a crime act and it is hard for him to adjust and believe in it. He would gradually feel that life with a paycheck is almost impossible, and little by little he would begin to join a corruption act (small or 
large), and then he finally believes that corruption is an inevitable evil - a necessary evil. At this time, he no longer customizes the behavior of conviction, but adjust his beliefs with his behavior instead. Toward the marginal construction carried out by the central government, the people in Natuna give a response with a substantive negotiation which implies resistance like political oppositions and cultural resistance. The political resistance is expressed in a form of demanding to the central government to make the Natuna status becoming an independent district. In response to the construction of the marginality from Jakarta, with the right momentum of the political change in Indonesia from authoritarian political system to democratic system in 1999, people in Natuna request to central government by demanding Natuna to serve as an independent district. The changing status of Natuna to become a district is a political victory of people in Natuna who have organized a political struggle and resistance to the central government as a consequence of the central government's treatment toward the marginalized the Natuna.

\section{Acknowledgement}

This research is supported by Indonesia Defense University research funding.

\section{References}

[1] Marsetio, "Pendayagunaan Wilayah Perbatasan dan Pulau-pulau Terluar guna Mendukung Pembangunan Nasional dalam rangka Persatuan dan Kesatuan Bangsa", Makalah pada Seminar Perwira Siswa Pendidikan Reguler XXXVI Sekolah Staf dan Komando Tentara Nasional, (2009); Jakarta, Indonesia.

[2] Z. Djafar, "Masyarakat Perbatasan RI - Malaysia dan Kasus Askar Wataniah: Relevansi Perubahan Kebijakan Kesejahteraan", dalam Jurnal Masyarakat dan Budaya, vol. 10, no. 1, (2008).

[3] S. K. Wahono, "Indonesia Negara Maritim", Jakarta: Teraju, (2009).

[4] Marsetio, "Pemberdayaan Masyarakat Perbatasan guna Meningkatkan Ketahanan Nasional dalam rangka Tetap Tegaknya Negara Kesatuan Republik Indonesia", Makalah pada hari ulang tahun Lembaga Ketahanan Nasional Republik Indonesia, (2010).

[5] G. Sumodiningrat, "Responsi Pemerintah terhadap Kesenjangan Ekonomi: Studi Empiris pada Kebijakan dan Program Pembangunan dalam rangka Pemberdayaan Masyarakat di Indonesia", (2001).

[6] R. Tirtosudarmo, "Wilayah Perbatasan dan Tantangan Abad 21: Sebuah Pengantar, dalam R Tirtosudiro, et al. Dari Entikong sampai Nunukan: Dinamika Daerah Perbatasan Kalimantan-Malaysia Timur (Serawak-Sabah)", Jakarta: Pustaka Sinar Harapan, (2005).

[7] M. Foucault, "Discipline and Punish: The Birth of the Prison", London: Penguin Books, (1982).

[8] Kusnadi, "Keberdayaan Nelayan dan Dinamika Ekonomi Pesisir", Yogyakarta: Arruzz Media, (2009).

[9] I. Abdullah, "Reorientasi Pembangunan Nasional: Menuju Indonesia yang Berdaulat dan Bermartabat", Jurnal Ketahanan Nasional, Yogyakarta: Program Studi Ketahanan Nasional, Sekolah Pascasarjana UGM, vol. 13, no. 3, (2008)

[10] A. D. Smith, "The Ethnic Origins of Nations", (1986), pp. 249-264.

[11] S. H. Mukti, "Konsep Pengembangan Kawasan Perbatasan Kalimantan", Indo-Malay Techno Agropolitan Corridor (IMTAC), Bulletin Tata Ruang, vol. 8-9, (2003).

[12] R. Ratti, How Can Existing Barriers and Border Effects be Overcome? A Theoretical Approach", Regional Networks, Border Regions and European Integration, (1993); Pion, London.

[13] R. Ratti, "Strategies to Overcome Barriers: From Theory to Practice", Theory and Practice of Transborder Cooperation, (1993), p. 241

[14] R. Ratti, "Spatial and Economic Effects of Frontiers: Overview of Traditional and New Approaches and Theories of Border Area Development", Theory and Practice of Transborder Cooperation, Basel Verlag Helbing \& Lichtenhahn, (1993).

[15] R. Ratti, "Spatial Effects of Frontiers", Overview of Different Approaches and Theories of Border Region Development, New Borders and Old Barriers in Spatial Development, (1994), pp. 15-33.

[16] C.-T. Wu, "Cross-Border Development in a Changing World: Redefining Regional Development Policies", Edgington, David W, et al. New Regional Development Paradigm, vol. 2, (2001), pp. 21-36.

[17] B. Anderson, "The Idea of Power in Java", Cultures and Politics in Indonesia, Ithaca: Cornell University Press, (1972).

[18] B. Anderson, "Majorities and Minorities in the Spectre of Comparisons: Nationalism", Southeast Asia and the World, (1998); Verso, London.

[19] P. Suparlan, "Orang Sakai di Riau: Masyarakat Terasing dalam Masyarakat Indonesia", Jakarta: Yayasan Obor Indonesia, (1995).

[20] Koentjaraningrat, "Masyarakat Terasing di Indonesia”, Jakarta: Gramedia Pustaka Utama, (1993). 
International Journal of $u-$ and $e^{-}$Service, Science and Technology

Vol.10, No.9 (2017) 